\title{
Article
}

\section{Future Healthcare Workers and Hepatitis B Vaccination: A New Generation}

\author{
Andrea Trevisan ${ }^{1, *(D)}$, Paola Mason ${ }^{1}$ (D), Annamaria Nicolli ${ }^{1}$, Stefano Maso ${ }^{1}$, Marco Fonzo ${ }^{1}$, Bruno Scarpa ${ }^{2} \mathbb{D}$ \\ and Chiara Bertoncello ${ }^{1}$ (D)
}

Citation: Trevisan, A.; Mason, P.; Nicolli, A.; Maso, S.; Fonzo, M.; Scarpa, B.; Bertoncello, C. Future Healthcare Workers and Hepatitis B Vaccination: A New Generation. Int. J. Environ. Res. Public Health 2021, 18, 7783. https://doi.org/10.3390/ ijerph18157783

Academic Editor: Paul B. Tchounwou

Received: 29 May 2021

Accepted: 21 July 2021

Published: 22 July 2021

Publisher's Note: MDPI stays neutral with regard to jurisdictional claims in published maps and institutional affiliations.

Copyright: (C) 2021 by the authors Licensee MDPI, Basel, Switzerland. This article is an open access article distributed under the terms and conditions of the Creative Commons Attribution (CC BY) license (https:// creativecommons.org/licenses/by/ $4.0 /)$.
1 Department of Cardiac Thoracic Vascular Sciences and Public Health, University of Padova, Via Giustiniani 2, 35128 Padova, Italy; paola.mason.1@unipd.it (P.M.); annamaria.nicolli@unipd.it (A.N.); stefano.maso@unipd.it (S.M.); marco.fonzo@unipd.it (M.F.); chiara.bertoncello@unipd.it (C.B.)

2 Department of Statistical Sciences, University of Padova, 35128 Padova, Italy; bruno.scarpa@unipd.it

* Correspondence: andrea.trevisan@unipd.it

\begin{abstract}
Before the introduction of universal vaccination, hepatitis B caused high morbidity and mortality, especially among healthcare workers. In the present study, the immune status against hepatitis B was assessed in a cohort of 11,188 students of the degree courses of the School of Medicine of the University of Padua (Italy) who had been subjected to mandatory vaccination in childhood or adolescence and who will be future healthcare workers. The variables that influence the antibody response to vaccination are mainly the age at which the vaccine was administered and sex. If vaccination was administered before one year of age, there is a high probability (around 50\%) of having an antibody titer lower than $10 \mathrm{IU} / \mathrm{L}$ compared to those vaccinated after one year of age $(12.8 \%)$. The time between vaccine and analysis is not decisive. Furthermore, female sex, but only if vaccination was administered after one year of age, shows a significant $(p=0.0008)$ lower percentage of anti-HBs below $10 \mathrm{IU} / \mathrm{L}$ and a greater antibody titer $(p<0.0001)$. In conclusion, the differences related to the age of vaccination induce more doubts than answers. The only plausible hypothesis, in addition to the different immune responses (innate and adaptive), is the type of vaccine. This is not easy to verify because vaccination certificates rarely report it.
\end{abstract}

Keywords: hepatitis B vaccination; healthcare workers; students; antibody titer; age at vaccination

\section{Introduction}

Hepatitis B (HBV) is a blood-borne transmittable infectious disease that before the introduction of universal vaccination (initially a plasma-derived and a successively genetically engineered Saccharomyces cerevisiae yeast recombinant vaccine) caused high levels of morbidity and mortality, especially among healthcare workers (HCWs) [1]. On the other hand, the attitude of HCWs to vaccination appears suboptimal [2,3].

With the implementation of mandatory vaccination in Italy in 1991 (for all newborns and adolescents of 12 years of age), morbidity has drastically reduced, especially in the more vulnerable age groups [4], passing from a country with medium endemicity to one with low endemicity.

The new generation of HCWs, those who have been mandatorily vaccinated since 1980, are now covered by the vaccine and, for the most part, they are also immune.

As it has been pointed out, a mandatory HBV vaccination campaign appears to be the best method for inducing immunity [5], but in Europe, mandatory vaccination is not homogeneous for newborns nor for HCWs [6].

Numerous research studies highlight the fact that mass vaccination induces a prolonged protective action [7-12] and how the presence of antibodies lower than $10 \mathrm{IU} / \mathrm{L}$, a value considered the cut-off between protection and non-protection, is not necessarily the cause of infection $[9,13,14]$. The attitude for vaccination against HBV and the anti-HBs titer 
in HCWs and in students has been evaluated in recent years and the majority of subjects investigated were protected even after many years [15-21].

Among the unprotected subjects, it is necessary to distinguish the so-called nonresponders who remain, fortunately limited to a modest percentage of cases, a problem; they are identified as someone who, as indicated by the Center for Disease Control and Prevention [22], "does not develop protective surface antibodies after completing two full series of the hepatitis B vaccine and for whom an acute or chronic hepatitis B infection has not been ruled out". The aim of this study was to assess the antibody titer against hepatitis B in the future generation of HCWs at the time of their university enrollment and to evaluate the effect of age at vaccination, sex, year of birth, and time between vaccination and antibody analysis on the antibody titer itself.

\section{Materials and Methods}

\subsection{Population}

The study enrolled 11,188 students (2004-2020) attending the Medical School (medicine and surgery, dentistry, and healthcare professions) of Padua University (Northern Italy). The enrollment criteria were that they had to be born in Italy and then vaccinated with the same schedule (three doses) and to present a certificate from the Public Health Office certifying the vaccination against HBV. The students attended graduate courses in medicine and surgery $(5121,45.8 \%)$, dentistry $(337,3.0 \%)$, and healthcare professions $(5730,51.2 \%)$. There were almost twice the number of females $(7291,65.2 \%)$ than males $(3897,34.8 \%)$, with the rate of males/females being 0.53 . The preponderance of the female sex is mainly due to the high presence of women in the study courses of healthcare professions (ratio 0.34 ) rather than in those of medicine and surgery (ratio 0.79 ) or dentistry (ratio 1.22).

The students were mainly from Northern Italy $(93.2 \%)$, in the Veneto Region $(85.0 \%)$, and, in particular, the Province of Padua (32.3\%). Those from Central and Southern Italy $(1.8 \%$ and $5.0 \%$, respectively) mainly attended the degree course in medicine. Figure 1 represents Italy and its subdivision into Northern, Central, and Southern regions.

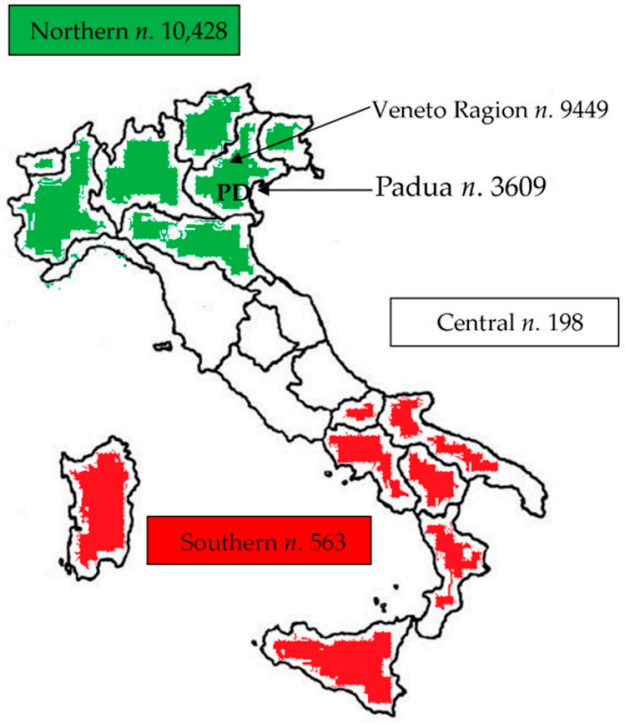

Figure 1. Representation of Italy divided into Northern (green), Central (white), and Southern (red) regions. The numbers of students from each of the three areas and in particular from the Veneto Region and the Province of Padua are specifically highlighted.

The students were further subdivided according to the age of vaccination (before one year of age or after) and into four-year birth groups (born between 1980 and 1985, between 1986 and 1990, between 1991 and 1995, and after 1995) to better highlight the differences in response to the vaccine according to the age of vaccination, which depends on the year of birth. 


\subsection{Antibody Measurement}

A commercial chemiluminescent microparticle immunoassay (CMIA) was used until 2017 to measure the anti-HBs titer. After that, at the end of 2017, the clinical microbiology laboratory changed the instrumentations and adopted a different commercial kit. The procedure uses a chemiluminescent immunoassay (CLIA) named LIAISON ${ }^{\circledR}$ anti-HBs plus by Sorin (Saluggia, Italy) and the lower cut-off is expressed only as below $3 \mathrm{IU} / \mathrm{L}$ without the possibility to know the values hidden under this value. For this reason, values indicated as below $3 \mathrm{IU} / \mathrm{L}$ were processed as $3 \mathrm{IU} / \mathrm{L}$. Similarly, the method does not provide values higher than $1000 \mathrm{IU} / \mathrm{L}$ and, therefore, for a statistical evaluation of the antibody titer, they were processed as $1000 \mathrm{IU} / \mathrm{L}$.

\subsection{Statistics}

A chi-squared $\left(\chi^{2}\right)$ test 2 by 2 (Yates' correction) was used to compare the frequencies of anti-HBs titers below $10 \mathrm{IU} / \mathrm{L}$ between different vaccination strategies and between year of birth. The presence of antibodies lower than $10 \mathrm{IU} / \mathrm{L}$ is considered the cut-off between protection and non-protection. Multiple linear regression based on the logarithm of the antibody titer (being asymmetric in its distribution) was employed to analyze the variables influencing antibody level (dependent variable). The following outcomes were considered for the purpose of multiple linear regression if appropriate (independent variables): (1) sex, (2) year of birth, and (3) time between the last dose of vaccine and analysis of antibodies. Statistical differences among antibody titers according to the age of vaccination and sex were evaluated by means of an unpaired t-test assuming unequal variance. In order to better highlight the possible differences between those vaccinated before and after one year of age, the subjects whose time between vaccine and analysis was between 16 and 25 years were extrapolated from both cohorts. The differences in terms of antibody titer and the prevalence of antibody levels lower than $10 \mathrm{IU} / \mathrm{L}$ were assessed with a parametric test as above for the former and with a chi-squared $\left(\chi^{2}\right)$ test for the latter. Other statistical analyses were descriptive. Significance is stated by $p<0.05$. Statsdirect 2.7 .7 version (Statsdirect Ltd., Birkenhead, Merseyside, UK) was used for the statistical analyses.

\section{Results}

The influence of sex and age at vaccination on the antibody response is shown in Table 1, where a significant difference is observed in all students both as a percentage of anti-HBs lower than $10 \mathrm{IU} / \mathrm{L}(p=0.0008)$ and the antibody titer $(p<0.0001)$ but only if they were vaccinated after the first year of age ( $p<0.0001$ for both parameters).

Table 1. Seroprevalence of anti-HBs lower than $10 \mathrm{IU} / \mathrm{L}$ and antibody titer for all students and the two cohorts vaccinated before or after the first year of age according to sex also. The last column shows the time between the last vaccine dose and the antibody analysis.

\begin{tabular}{|c|c|c|c|c|c|c|c|c|}
\hline Students & $n$ & $<10 \mathrm{IU} / \mathrm{L}$ & $\%$ & $x^{2}$ & $p$ & Titer IU/L Mean \pm SD & $p$ & Time Mean \pm SD \\
\hline All students & 11,188 & 3679 & 32.9 & 11.144 & $=0.0008 *$ & $166.0 \pm 288.7$ & $<0.0001 *$ & $15.3 \pm 4.9$ \\
\hline males & 3897 & 1361 & 34.9 & & & $143.3 \pm 265.5$ & & $15.9 \pm 4.7$ \\
\hline females & 7291 & 2318 & 31.8 & & & $178.2 \pm 299.8$ & & $15.1 \pm 5.0$ \\
\hline \multicolumn{9}{|l|}{ Age at vaccination } \\
\hline $\begin{array}{c}\text { Vaccinated before } 1 \\
\text { year of age }\end{array}$ & 6013 & 3017 & 50.2 & 1759.371 & $<0.0001 * *$ & $50.1 \pm 127.9$ & $<0.0001^{* *}$ & $19.4 \pm 1.1$ \\
\hline males & 2179 & 1080 & 49.6 & 0.472 & n.s. & $51.8 \pm 129.7$ & n.s. & $19.5 \pm 1.0$ \\
\hline females & 3834 & 1937 & 50.5 & & & $49.1 \pm 126.8$ & & $19.3 \pm 1.1$ \\
\hline $\begin{array}{c}\text { Vaccinated after } 1 \text { year } \\
\text { of age }\end{array}$ & 5175 & 662 & 12.8 & & & $300.7 \pm 357.1$ & & $10.7 \pm 3.2$ \\
\hline males & 1718 & 281 & 16.4 & 28.805 & $<0.0001 *$ & $259.3 \pm 338.4$ & $<0.0001 *$ & $11.3 \pm 3.2$ \\
\hline females & 3457 & 381 & 11.0 & & & $321.3 \pm 364.3$ & & $10.3 \pm 3.1$ \\
\hline
\end{tabular}

* Statistical significance of the differences between males and females, where females have a lower percentage of anti-HBs lower than $10 \mathrm{IU} / \mathrm{L}$ and a higher antibody titer; ** statistical significance of the differences between all students vaccinated before or after one year of age. n.s. = not significant 
Figure 2 illustrates how the antibody titer and the prevalence of subjects below $10 \mathrm{IU} / \mathrm{L}$ is related to the year of birth (1991-1992) in which infants were vaccinated at three months of age.

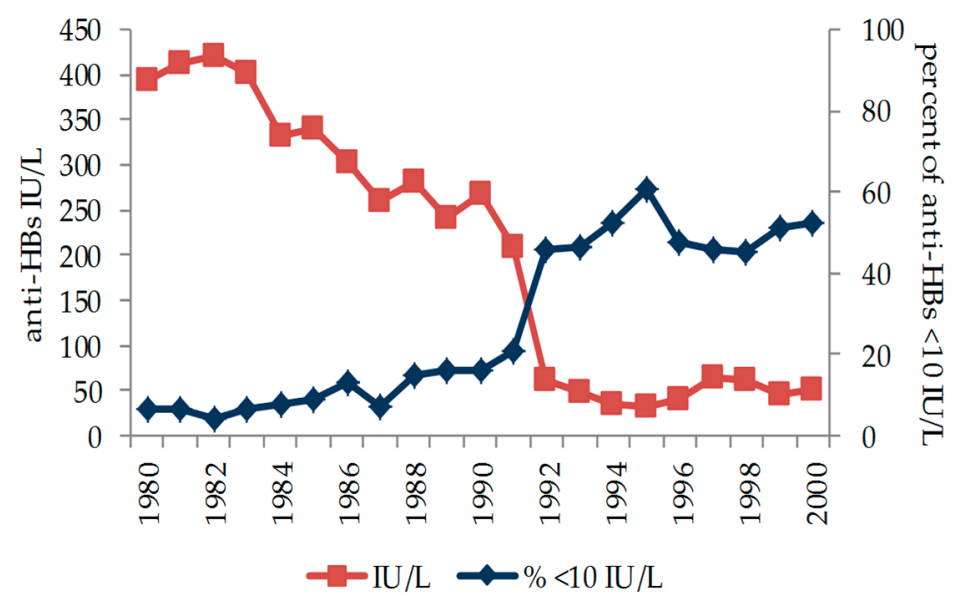

Figure 2. Antibody titer level (IU/L) and antibody titer lower than $10 \mathrm{IU} / \mathrm{L}$ according to year of birth 1980-2000. Those born before 1 January 1992 were vaccinated at 12 years of age, with those born after being vaccinated at 3 months of age, in compliance with the vaccination schedule adopted at the beginning of the mandatory vaccination campaign against HBV.

To define once and for all whether the interval between the vaccine and analysis is determined to cause both a consistent reduction in the antibody titer and a high percentage of subjects with a titer lower than $10 \mathrm{IU} / \mathrm{L}, \mathrm{f}$ those with the same time between 16 and 25 years were extrapolated from the context (Table 2). With the same time, the statistically significant difference $(p<0.0001)$ regards the percentage of antibodies lower than $10 \mathrm{IU} / \mathrm{L}$ and the antibody titer remains in favor of those vaccinated after one year of age.

Table 2. Seroprevalence of anti-HBs lower than $10 \mathrm{IU} / \mathrm{L}$ and titer according to vaccination before and after the first year of age with a time between vaccine and analysis of antibodies between 16 and 25 years.

\begin{tabular}{cccccccc}
\hline Time All $\geq \mathbf{1 6}$ Years & $\boldsymbol{n}$ & $<\mathbf{1 0} \mathrm{IU} / \mathrm{L}$ & $\mathbf{\%}$ & $\chi^{\mathbf{2}}$ & $\boldsymbol{p}$ & Titer IU/L Mean \pm SD & $\boldsymbol{p}$ \\
\hline vaccinated before 1 year & 6013 & 3017 & 50.2 & 165.235 & $<0.0001$ & $50.1 \pm 127.9$ & $<0.0001$ \\
vaccinated after 1 year & 383 & 62 & 16.2 & & & $222.0 \pm 314.7$ & \\
\hline
\end{tabular}

Further, between those vaccinated before and after one year of age, there are individuals (relatively few) who are outside the canonical ages established by the law. In both cases, birth before 1990 shows, although not always significantly, a lower percentage of anti-HBs below $10 \mathrm{IU} / \mathrm{L}$ and a higher antibody titer (Table 3).

Table 3. Seroprevalence of anti-HBs lower than $10 \mathrm{IU} / \mathrm{L}$ and titer according to vaccination before and after the first year of age and date of birth between 1980 and 1990 or after.

\begin{tabular}{|c|c|c|c|c|c|c|c|c|}
\hline Vaccination & $n$ & $<10 \mathrm{IU} / \mathrm{L}$ & $\%$ & $x^{2}$ & $p$ & Titer IU/L Mean \pm SD & $p$ & Time Mean \pm SD \\
\hline before 1 year of age & & & & 0.273 & n.s. & & & \\
\hline born 1980-1990 & 36 & 16 & 44.4 & & & $114.9 \pm 254.9$ & & $20.1 \pm 1.9$ \\
\hline born in 1991 or after & 5977 & 3001 & 50.2 & & & $49.7 \pm 126.7$ & $=0.0023$ & $19.4 \pm 1.0$ \\
\hline $\begin{array}{l}\text { after } 1 \text { year of age } \\
\text { born } 1980-1990\end{array}$ & 4573 & 558 & 12.2 & 11.825 & $=0.0006$ & $308.6 \pm 360.3$ & & $10.7 \pm 3.1$ \\
\hline born in 1991 or after & 602 & 104 & 17.3 & & & $241.1 \pm 325.7$ & $<0.0001$ & $10.1 \pm 3.5$ \\
\hline
\end{tabular}

Multiple linear regression based on the logarithm of the antibody titer identified three independent variables, namely year of birth, sex, and time between the third dose of the vaccine and analysis of antibodies. 
Overall, year of birth and time between vaccine and analysis significantly affect $(p<0.0001)$ the antibody response, whereas sex is only significant if students were vaccinated after the first year of age (Table 4).

Table 4. Multiple linear regression on the influence of independent variables on the anti-HBs titer (logarithmic transformation) in all students and in two cohorts of those vaccinated before or after the first year of age. Significant results are in bold.

\begin{tabular}{ccccc}
\hline All Students & $\mathbf{b}$ & $\boldsymbol{r}$ & $\mathbf{t}$ & $\boldsymbol{p}$ \\
\hline Intercept & 101.326457 & & 23.188326 & $<0.0001$ \\
year of birth & -0.049739 & -0.208528 & -22.548445 & $<0.0001$ \\
sex & 0.031555 & 0.017194 & 1.818617 & $=0.069$ \\
time & -0.000152 & -0.228768 & -24.852321 & $<0.0001$ \\
\hline Vaccinated before 1 year of age & $\mathbf{b}$ & $\boldsymbol{r}$ & $\mathbf{t}$ & $\boldsymbol{p}$ \\
\hline Intercept & -34.537893 & & -3.868822 & $<0.0001$ \\
year of birth & 0.017517 & 0.050819 & 3.944496 & $<0.0001$ \\
sex & -0.035231 & -0.019884 & -1.541681 & $=0.1232$ \\
time & 0.000086 & 0.036904 & 2.862629 & $=0.0042$ \\
\hline Vaccinated after 1 year of age & $\mathbf{b}$ & $\boldsymbol{r}$ & $\mathbf{t}$ & $\boldsymbol{p}$ \\
\hline Intercept & 110.800937 & & 13.20865 & $<0.0001$ \\
year of birth & -0.054679 & -0.17756 & -12.974467 & $<0.0001$ \\
sex & 0.148749 & 0.079279 & 5.718946 & $<0.0001$ \\
time & -0.000075 & -0.092701 & -6.694957 & $<0.0001$ \\
\hline
\end{tabular}

\section{Discussion}

In 1992, the WHO included HBV vaccination to among those recommended, but in Italy, the mandatory mass vaccination had already started in 1991 for newborns and adolescents. Incomprehensibly, no vaccinations are mandatory in Italy for HCWs, not even that against HBV. Fortunately, given the introduction of mandatory vaccination for those born since 1980, we have a new generation and will have future generations of vaccinated HCWs.

Vaccination against $\mathrm{HBV}$ is safe, and immunity lasts a long time [7,12,21,23]. A cutoff of $10 \mathrm{IU} / \mathrm{L}$ is the watershed to consider antibody levels protective [14], although it has been widely demonstrated that immune memory persists despite very low antibody titers [24-26].

The results of this study highlight that there are many variables that can influence the level of antibodies against HBV. The year of birth and consequently the age of administration of the first dose of the vaccine is the variable most influencing the antibody response.

We have long argued that vaccination administered before one year of age has, as a consequence, a high percentage of subjects with antibody levels lower than $10 \mathrm{IU} / \mathrm{L}$ and a low antibody titer [27]. The current results, on a 10-times higher number of cases, confirm this. The obvious objection is that the time between the vaccine and antibody analysis is almost double that between the two cohorts. To dispel any doubts, the two cohorts were again compared in relation to the time and the results were comparable to the previous ones [27].

If time is not the deciding factor, why are there such discrepancies? We tried to test (unfortunately the numbers are small) whether there was a difference between the two cohorts in relation to the year of birth. The difference is evident above all for the antibody titer. Vaccination after one year of age induces a higher antibody titer (independently by the time elapsed between the last vaccine dose and the antibody analysis), probably in relation to the development of adaptive immunity.

Another hypothesis, which could be supported by the evidence that birth in the decade 1980-1990, even if vaccinated before one year, gives better results, in particular for the antibody titer, is the type of vaccine. As already highlighted $[25,28]$, the Engerix- $\mathrm{B}^{\circledR}$ 
vaccine is far more immunogenic than the Recombivax $\mathrm{HB}^{\circledR}$ vaccine, even in the hexavalent formulation; however, the latter came into use in the mid-eighties and was subsequently replaced by others [29]. The lower efficacy of the Recombivax $\mathrm{HB}^{\circledR}$ vaccine has been well documented $[29,30]$. Currently, there are no other acceptable explanations, and this is surely a weakness of the study.

Despite this, the disappearance of the circulating antibodies does not signify a loss of the immune response [31]. The activation of T lymphocytes permits HBsAg-specific memory persistence [32]. Protection induced by the HBV vaccine has been associated with specific SNPs encoding cytokines and TLR2. On the contrary, non-responders more frequently express SNPs rs1 143633 (IL-1B; intron) and rs1 143627 (IL-1B; intron) that define the AG haplotype [33].

In detail, the polymorphism of the IL4 gene is fundamental for the response to the vaccine [34], while polymorphisms of the immunoregulatory cytokines and $H L A-D R B 1^{*} 07$ genes cause a variable response to recombinant vaccines [35]. The scenario in the case of non-response to the HBV vaccine appears more complex. The causes can be ascribed to adequate production of Th1-and Th2-like cytokines [36], changes in the expression in CXCR5 associated with polymorphisms in follicular helper T cells [37], and the TT genotype of the IFNG (+874 T/A) gene and alleles 170 and 182 for the (CA)n alleles for the intronic (CA)n microsatellite of the IFNGR1 gene [38]. A prompt response after a booster dose reveals an effective immune memory [8,39], whereas low antibody production suggests a loss of immune memory [40]. Most subjects with a non-protective antibody titer $(<10 \mathrm{IU} / \mathrm{L})$ produce anti-HBs after the booster due to activation of B cells [41]. In contrast, non-responders have a low B cell response [42]. Further, immune memory persists for at least five years in children vaccinated as infants [43].

Finally, the response to a booster dose is similar in the two cohorts $[25,26]$. Thus, maintaining long-term protection from a routine booster is unnecessary [44].

Recently [45], we suggested a different response to the HBV vaccine related to sex, and also after a booster dose [26]. However, a significant difference was observed only in those vaccinated after one year of age in terms of the antibody titer and values below $10 \mathrm{IU} / \mathrm{L}$. In fact, although innate immunity is similar [46], adaptive immunity is more pronounced in females, and this justifies the discrepancy between the two cohorts. Adaptive immunity depends on three fundamental components, such as $\mathrm{B}$ cells, $\mathrm{CD} 4^{+} \mathrm{T}$ cells, and $\mathrm{CD} 8^{+} \mathrm{T}$ cells [47]. As estrogens have a high role in adaptive immunity [48], a major response in females appears an obvious consequence.

Finally, measurement of the anti-HBs titer, at least during the first health surveillance, is useful to identify the (few) HCWs with antibody titer below that considered protective [15-17].

This study has some limitations. First, we were not able to retrieve the data on the type of vaccine administered (either Engerix- $\mathrm{B}^{\circledR}$ or Recombivax $\mathrm{HB}^{\circledR}$ ) at the individual level, and second, the method used to assess the antibody titers does not provide values higher than $1000 \mathrm{IU} / \mathrm{L}$ and this may have affected statistical analyses.

\section{Conclusions}

The results of this research pose many questions and the answers are neither easy nor definitive. The main question that has tormented us for years is why vaccinating before one year of age, even with the same time between the vaccine and analysis, shows a remarkable difference both in terms of the antibody titer and the prevalence of antibodies lower than $10 \mathrm{IU} / \mathrm{L}$. The type of vaccine could be responsible for the observed differences, but we do not know for certain because the vaccine certificates do not report the type. The lack of knowledge of the type of vaccine is certainly a weakness of the study. However, we suggest that in low endemicity countries, HBV vaccination should be performed after one year of age. 
Author Contributions: Conceptualization, A.T., C.B. and P.M.; methodology, C.B. and M.F.; validation, S.M. and A.N.; formal analysis, B.S.; data curation, A.T., C.B. and M.F.; investigation, A.T. and P.M.; writing—original draft preparation, A.T.; writing-review and editing, A.T., C.B., A.N. and P.M.; supervision, A.T. All authors have read and agreed to the published version of the manuscript.

Funding: This research received no external funding.

Institutional Review Board Statement: This was an observational study in which we analyzed data from a mandatory health surveillance activity on workers exposed to biological risk regulated by the Italian legislative decree $81 / 2008$; consequently, the evaluation by an ethics committee was not necessary.

Informed Consent Statement: Students subscribed to an information note on the processing of personal and sensitive information in which they also expressed consent to the possibility of the data collected being processed anonymously for epidemiological investigations and/or for scientific research purposes.

Data Availability Statement: Raw data are available upon request from the corresponding author.

Conflicts of Interest: The authors declare no conflict of interest.

\section{References}

1. Agerton, T.B.; Mahoney, F.J.; Polish, L.B.; Shapiro, C.N. Impact of the bloodborne pathogens standard on vaccination of healthcare workers with hepatitis B vaccine. Infect. Control. Hosp. Epidemiol. 1995, 16, 287-291. [CrossRef]

2. Maltezou, H.C.; Lourida, A.; Katragkou, A.; Grivea, I.N.; Katerelos, P.; Wicker, S.; Syrogiannopoulos, G.A.; Roilides, E.; Theodoridou, M. Attitudes regarding occupational vaccines and vaccination coverage against vaccine-preventable diseases among healthcare workers working in pediatric departments in Greece. Pediatr. Infect. Dis. J. 2012, 31, 623-625. [CrossRef] [PubMed]

3. Maltezou, H.C.; Katerelos, P.; Poufta, S.; Pavli, A.; Maragos, A.; Theodoridou, M. Attitudes toward mandatory occupational vaccinations and vaccination coverage against vaccine-preventable diseases of health care workers in primary health care centers. Am. J. Infect. Control. 2013, 41, 66-70. [CrossRef] [PubMed]

4. Stroffolini, T.; Mele, A.; Tosti, M.E.; Gallo, G.; Balocchini, E.; Ragni, P.; Santonastasi, F.; Marzolini, A.; Ciccozzi, M.; Moiraghi, A. The impact of the hepatitis B mass immunisation campaign on the incidence and risk factors of acute hepatitis B in Italy. J. Hepatol. 2000, 33, 980-985. [CrossRef]

5. Trevisan, A.; Borella-Venturini, M.; Di Marco, L. Compliance with hepatitis B virus vaccine: A matter of force? Am. J. Infect. Control. 2006, 34, 465-466. [CrossRef] [PubMed]

6. Trevisan, A.; Nicolli, A.; Chiara, F. Hepatitis B: Prevention, protection, and occupational risk. Future Virol. 2015, $10,53-61$. [CrossRef]

7. Floreani, A.; Baldo, V.; Cristofoletti, M.; Renzulli, G.; Valeri, A.; Zanetti, C.; Trivello, R. Long-term persistence of anti-HBs after vaccination against HBV: An 18 year experience in health care workers. Vaccine 2004, 22, 607-610. [CrossRef]

8. Zanetti, A.R.; Mariano, A.; Romanò, L.; D'Amelio, R.; Chironna, M.; Coppola, R.C.; Cuccia, M.; Mangione, R.; Marrone, F.; Negrone, F.S.; et al. Long-term immunogenicity of hepatitis B vaccination and policy for booster: An Italian multicentre study. Lancet 2005, 366, 1379-1384. [CrossRef]

9. McMahon, B.J.; Bruden, D.L.; Petersen, K.M.; Bulkow, L.R.; Parkinson, A.J.; Nainan, O.; Khristova, M.; Zanis, C.; Peters, H.; Margolis, H.S. Antibody levels and protection after hepatitis B vaccination: Results of a 15-year follow-up. Ann. Intern. Med. 2005, 142, 333-341. [CrossRef]

10. Gabbuti, A.; Romanò, L.; Blanc, P.; Meacci, F.; Amendola, A.; Mele, A.; Mazzotta, F.; Zanetti, A.R. Long-term immunogenicity of hepatitis B vaccination in a cohort of Italian healthy adolescents. Vaccine 2007, 25, 3129-3132. [CrossRef]

11. Alfaleh, F.; Alshehri, S.; Alansari, S.; Aljeffri, M.; Almazrou, Y.; Shaffi, A.; Abdo, A.A. Long-term protection of hepatitis B vaccine 18 years after vaccination. J. Infect. 2008, 57, 404-409. [CrossRef] [PubMed]

12. Trevisan, A. Long-term persistence of immunity after hepatitis B vaccination: A fact, not a fancy. Hum. Vaccines Immunother. 2017, 13, 916-917. [CrossRef] [PubMed]

13. Alimonos, K.; Nafziger, A.N.; Murray, J.; Bertino, J.S., Jr. Prediction of response to hepatitis B vaccine in health care workers: Whose titers of antibody to hepatitis B surface antigen should be determined after a three-dose series, and what are the implications in terms of cost-effectiveness? Clin. Infect. Dis. 1998, 26, 566-571. [CrossRef]

14. Jack, A.D.; Hall, A.J.; Maine, N.; Mendy, M.; Whittle, H.C. What level of hepatitis B antibody is protective? J. Infect. Dis. 1999, 179, 489-492. [CrossRef] [PubMed]

15. Batra, V.; Goswami, A.; Dadhich, S.; Kothari, D.; Bhargava, N. Hepatitis B immunization in healthcare workers. Ann. Gastroenterol. 2015, 28, 276-280. [PubMed] 
16. Lamberti, M.; De Rosa, A.; Garzillo, E.M.; Corvino, A.R.; Sannolo, N.; De Pascalis, S.; Di Fiore, E.; Westermann, C.; Arnese, A.; Di Giuseppe, G.; et al. Vaccination against hepatitis b virus: Are Italian medical students sufficiently protected after the public vaccination programme? J. Occup. Med. Toxicol. 2015, 10, 41. [CrossRef] [PubMed]

17. Verso, M.G.; Lo Cascio, N.; Noto Laddeca, E.; Amodio, E.; Currieri, M.; Giammanco, G.; Ferraro, D.; De Grazia, S.; Picciotto, D. Predictors of Hepatitis B Surface Antigen Titers two decades after vaccination in a cohort of students and post-graduates of the Medical School at the University of Palermo, Italy. Ann. Agric. Environ. Med. 2017, 24, 303-306. [CrossRef]

18. Coppeta, L.; Pompei, A.; Balbi, O.; Zordo, L.M.; Mormone, F.; Policardo, S.; Lieto, P.; Pietroiusti, A.; Magrini, A. Persistence of Immunity for Hepatitis B Virus among Heathcare Workers and Italian Medical Students 20 Years after Vaccination. Int. J. Environ. Res. Public Health 2019, 16, 1515. [CrossRef] [PubMed]

19. Hiva, S.; Negar, K.; Parsaei, M.R.; Ghorbani, G.R.; Aarabi, M.; Nadi Ghara, A.A.; Saffar, M.J. High level of vaccination and protection against hepatitis B with low rate of HCV infection markers among hospital health care personnel in north of Iran: A cross-sectional study. BMC Public Health 2020, 20, 920. [CrossRef]

20. van Leeuwen, L.P.M.; Doornekamp, L.; Goeijenbier, S.; de Jong, W.; de Jager, H.J.; van Gorp, E.C.M.; Goeijenbier, M. Evaluation of the Hepatitis B Vaccination Programme in Medical Students in a Dutch University Hospital. Vaccines 2021, 9, 69. [CrossRef] [PubMed]

21. Cocchio, S.; Baldo, V.; Volpin, A.; Fonzo, M.; Floreani, A.; Furlan, P.; Mason, P.; Trevisan, A.; Scapellato, M.L. Persistence of anti-HBs after up to 30 years in health care workers vaccinated against hepatitis B virus. Vaccines 2021, 9, 323. [CrossRef] [PubMed]

22. Advisory Committee on Immunization Practices; Centers for Disease Control and Prevention (CDC). Immunization of health-care personnel: Recommendations of the Advisory Committee on Immunization Practices (ACIP). MMWR Recomm. Rep. 2011, 60, $1-45$.

23. Poovorawan, Y.; Chongsrisawat, V.; Theamboonlers, A.; Bock, H.L.; Leyssen, M.; Jacquet, J.M. Persistence of antibodies and immune memory to hepatitis B vaccine 20 years after infant vaccination in Thailand. Vaccine 2010, 28, 730-736. [CrossRef]

24. Spradling, P.R.; Xing, J.; Williams, R.; Masunu-Faleafaga, Y.; Dulski, T.; Mahamud, A.; Drobeniuc, J.; Teshale, E.H. Immunity to hepatitis B virus (HBV) infection two decades after implementation of universal infant HBV vaccination: Association of detectable residual antibodies and response to a single HBV challenge dose. Clin. Vaccine Immunol. 2013, 20, 559-561. [CrossRef]

25. Chiara, F.; Bartolucci, G.B.; Cattai, M.; Piazza, A.; Nicolli, A.; Buja, A.; Trevisan, A. Hepatitis B vaccination of adolescents: Significance of non-protective antibodies. Vaccine 2014, 32, 62-68. [CrossRef] [PubMed]

26. Trevisan, A.; Frasson, C.; De Nuzzo, D.; Nicolli, A.; Scapellato, M.L. Significance of anti-HB levels below 10 IU/L after vaccination against hepatitis B in infancy or adolescence: An update in relation to sex. Hum. Vaccines Immunother. 2020, 16, 460-464. [CrossRef] [PubMed]

27. Chiara, F.; Bartolucci, G.B.; Mongillo, M.; Ferretto, L.; Nicolli, A.; Trevisan, A. Hepatitis B vaccination at three months of age: A successful strategy? Vaccine 2013, 31, 1696-1700. [CrossRef] [PubMed]

28. Lee, G.H.; Lim, S.G. CpG-Adjuvanted Hepatitis B Vaccine (HEPLISAV-B ${ }^{\circledR}$ ) Update. Expert Rev. Vaccines 2021, $20,487-495$. [CrossRef] [PubMed]

29. Zanetti, A.R.; Romanò, L.; Giambi, C.; Pavan, A.; Carnelli, V.; Baitelli, G.; Malchiodi, G.; Valerio, E.; Barale, A.; Marchisio, M.A.; et al. Hepatitis B immune memory in children primed with hexavalent vaccines and given monovalent booster vaccines: An open-label, randomised, controlled, multicentre study. Lancet Infect. Dis. 2010, 10, 755-761. [CrossRef]

30. Keating, G.M.; Noble, S. Recombinant hepatitis B vaccine (Engerix-B): A review of its immunogenicity and protective efficacy against hepatitis B. Drugs 2003, 63, 1021-1052. [CrossRef]

31. Wenzel, J.J.; Jilg, W. Loss of antibodies, but not of protection. Lancet Infect. Dis. 2010, 10, 738-739. [CrossRef]

32. Leroux-Roels, G.; Van Hecke, E.; Michielsen, W.; Voet, P.; Hauser, P.; Pêtre, J. Correlation between in vivo humoral and in vitro cellular immune responses following immunization with hepatitis B surface antigen (HBsAg) vaccines. Vaccine 1994, 12, 812-818. [CrossRef]

33. Chen, J.; Liang, Z.; Lu, F.; Fang, X.; Liu, S.; Zeng, Y.; Zhu, F.; Chen, X.; Shen, T.; Li, J.; et al. Toll-like receptors and cytokines/cytokine receptors polymorphisms associate with non-response to hepatitis B vaccine. Vaccine 2011, $29,706-711$. [CrossRef] [PubMed]

34. Cui, W.; Sun, C.M.; Deng, B.C.; Liu, P. Association of polymorphisms in the interleukin-4 gene with response to hepatitis B vaccine and susceptibility to hepatitis B virus infection: A meta-analysis. Gene 2013, 525, 35-40. [CrossRef]

35. Wang, C.; Tang, J.; Song, W.; Lobashevsky, E.; Wilson, C.M.; Kaslow, R.A. HLA and cytokine gene polymorphisms are independently associated with responses to hepatitis B vaccination. Hepatology 2004, 39, 978-988. [CrossRef] [PubMed]

36. Kardar, G.A.; Jeddi-Tehrani, M.; Shokri, F. Diminished Th1 and Th2 cytokine production in healthy adult nonresponders to recombinant hepatitis B vaccine. Scand. J. Immunol. 2002, 55, 311-314. [CrossRef]

37. Duan, Z.; Chen, X.; Liang, Z.; Zeng, Y.; Zhu, F.; Long, L.; McCrae, M.A.; Zhuang, H.; Shen, T.; Lu, F. Genetic polymorphisms of CXCR5 and CXCL13 are associated with non-responsiveness to the hepatitis B vaccine. Vaccine 2014, 32, 5316-5322. [CrossRef] [PubMed]

38. Çiftdoğan, D.Y.; Onay, H.; Tosun, S.; Özdemir, T.R.; Özkinay, F.; Vardar, F. IFNG and IFNGR1 gene polymorphisms in children with nonresponse to the hepatitis B vaccine. Future Virol. 2014, 9, 123-130. [CrossRef] 
39. Roznovsky, L.; Orsagova, I.; Kloudova, A.; Tvrdik, J.; Kabieszova, L.; Lochman, I.; Mrazek, J.; Hozakova, L.; Zjevikova, A.; Pliskova, L. Long-term protection against hepatitis B after newborn vaccination: 20-year follow-up. Infection 2010, 38, 395-400. [CrossRef] [PubMed]

40. Jan, C.F.; Huang, K.C.; Chien, Y.C.; Greydanus, D.E.; Davies, H.D.; Chiu, T.Y.; Huang, L.M.; Chen, C.J.; Chen, D.S. Determination of immune memory to hepatitis B vaccination through early booster response in college students. Hepatology 2010, 51, 1547-1554. [CrossRef]

41. Bauer, T.; Jilg, W. Hepatitis B surface antigen-specific T and B cell memory in individuals who had lost protective antibodies after hepatitis B vaccination. Vaccine 2006, 24, 572-577. [CrossRef] [PubMed]

42. Valats, J.C.; Tuaillon, E.; Funakoshi, N.; Hoa, D.; Brabet, M.C.; Bolloré, K.; Ducos, J.; Vendrell, J.P.; Blanc, P. Investigation of memory $\mathrm{B}$ cell responses to hepatitis B surface antigen in health care workers considered as non-responders to vaccination. Vaccine 2010, 28, 6411-6416. [CrossRef]

43. Carollo, M.; Palazzo, R.; Bianco, M.; Pandolfi, E.; Chionne, P.; Fedele, G.; Tozzi, A.E.; Carsetti, R.; Romanò, L.; Ausiello, C.M. Hepatitis B specific T cell immunity induced by primary vaccination persists independently of the protective serum antibody level. Vaccine 2013, 31, 506-513. [CrossRef] [PubMed]

44. European Consensus Group on Hepatitis B Immunity. Are booster immunisations needed for lifelong hepatitis B immunity? Lancet 2000, 355, 561-565. [CrossRef]

45. Trevisan, A.; Giuliani, A.; Scapellato, M.L.; Anticoli, S.; Carsetti, R.; Zaffina, S.; Brugaletta, R.; Vonesch, N.; Tomao, P.; Ruggieri, A. Sex Disparity in Response to Hepatitis B Vaccine Related to the Age of Vaccination. Int. J. Environ. Res. Public Health 2020, 17, 327. [CrossRef]

46. Klein, S.L.; Jedlicka, A.; Pekosz, A. The Xs and Y of immune responses to viral vaccines. Lancet Infect. Dis. 2010, 10, 338-349. [CrossRef]

47. Sette, A.; Crotty, S. Adaptive immunity to SARS-CoV-2 and COVID-19. Cell 2021, 184, 861-880. [CrossRef] [PubMed]

48. Moulton, V.R. Sex Hormones in Acquired Immunity and Autoimmune Disease. Front. Immunol. 2018, 9, 2279. [CrossRef] 